\title{
The inhibitory effect of biofilms produced by wild bacterial isolates to the larval settlement of the fouling ascidia Ciona intestinalis and Pyura praeputialis
}

\author{
Manuel Zapata \\ Laboratorio de Ecología Microbiana \\ Departamento de Acuicultura \\ Facultad de Recursos del Mar \\ Universidad de Antofagasta \\ Av. Jaime Guzmán s/n Casilla 170 \\ Antofagasta, Chile \\ Tel: 5655637881 \\ Fax: 5655637804 \\ E-mail: mzarcos@gmail.com
}

Fernando Silva

Laboratorio de Ecología Microbiana

Departamento de Acuicultura

Facultad de Recursos del Mar

Universidad de Antofagasta

Av. Jaime Guzmán s/n Casilla 170

Antofagasta, Chile

Tel: 5655637881

Fax: 5655637804

E-mail: fsaciares@gmail.com

\section{Yery Luza}

Laboratorio de Ecología Microbiana

Departamento de Acuicultura

Facultad de Recursos del Mar

Universidad de Antofagasta

Av. Jaime Guzmán s/n Casilla 170

Antofagasta, Chile

Tel: 5655637881

Fax: 5655637804

E-mail: yerynaram@gmail.com

\section{Marcela Wilkens}

Laboratorio de Microbiología Molecular

Departamento de Biología

Universidad de Santiago

Av Lib Bernardo O'Higgins 3363

Estación Central, Santiago, Chile

Tel: 5655637881

Fax: 5655637804

E-mail: mwilkens@lauca.usach.cl

\section{Carlos Riquelme*}

Laboratorio de Ecología Microbiana

Departamento de Acuicultura

Facultad de Recursos del Mar

Universidad de Antofagasta

Av. Jaime Guzmán s/n Casilla 170

Antofagasta, Chile

Tel: 5655637881

Fax: 5655637804

E-mail: ceriquelme@gmail.com

Financial support: Chilean National Fund for Promotion of Scientific and Technological Development (FONDEF) project N DO1I1166.

Keywords: antifouling extracts, ascidian bioassays, bacterial biofilms, Ciona intestinalis, marine biofouling, natural antifoulants, Pyura praeputialis.

*Corresponding author 
Abbreviations: HPLC: high pressure liquid chromatrography MMM: marine minimal medium TBT: tributyl-tin
Marine biofouling is a present and potentially increasing future problem at molluscan culture centres. The problem is highly variable, exists on different scales, and its negative impact on cultured organisms and related economic losses at these centres has not been significantly controlled. One approach to fouling control has been the incorporation of natural substances into anti-fouling paints which inhibit the settlement of common fouling organisms. The main objective of the present study was the isolation of naturally occurring substances from marine bacteria which were inhibitory to the settlement of Ciona intestinalis and Pyura praeputialis, two tunicate species causing serious fouling problems in scallop culture systems in Chile. Numerous bacterial strains were isolated from microfouling on natural and artificial substrates submerged in the sea; of 73 strains isolated, $20 \%$ demonstrated inhibitory effects on the settlement of the larvae of the above cited tunicates. The inhibitory substances produced by the active bacteria were extracellular, and could be incorporated in an inert matrix (Phytagel ${ }^{\mathrm{TM}}$ ) without losing their inhibitory properties. Some properties of the inhibitory substance isolated from bacterial strain Clon Nil-LEM (Alteromonas sp) included thermostability, MW $<3500$ Da, peptidase lability (against $C$. intestinalis), and undiminished inhibitory activity when incorporated in the inert matrix.

Biofouling causes severe problems for structures submerged in the sea, such as increases in mass, and corrosion of surfaces resulting in economic losses. These effects are of particular consequence in the aquaculture industry, and on structures in the sea such as the supports of oil drilling platforms and ship hulls (Armstrong et al.
2000). A common method for avoiding settlement of marine fouling organisms on marine structures has been coating with antifouling paints, preferably those containing tributyl-tin (TBT) or copper. These paints are highly effective in controlling fouling on ships, with periods of up to seven years without maintenance and representing savings of US\$ 6.5 billion per year. Considerations of environmental protection, however, now prevent use of the TBT coatings on vessels of under $25 \mathrm{~m}$ in length. Numerous studies have been made on the effects of TBT on marine organisms such as the molluscs, in which toxic doses may be as low as $1 \mathrm{ng} \mathrm{L}^{-1}$ (Grinwis et al. 1998; Fisher et al. 1999).

Environmentally acceptable antifouling substances are needed for incorporation into antifouling coatings, and these may include natural products isolated from certain marine organisms (Clare, 1996) which natural products isolated from certain marine organisms (Clare, 1996). Incorporation of naturally repellent products into antifouling paints has been tried by some researchers (Armstrong et al. 2000; Peppiatt et al. 2000). Some marine organisms such as corals, algae, sponges, and ascidians have been shown to produce antifouling substances which in nature maintain them free from undesirable encrusting organisms (Hentschel et al. 2001; Dobretsov and Qian 2002; Harder et al. 2003).

Some studies have shown that bacterial biofilms isolated from organisms having low degrees of surface macrofouling release compounds which repel other bacteria, acting in a protective role (Boyd et al. 1998; Boyd et al. 1999a; Boyd et al. 1999b; Burgess et al. 2003).Some bacteria present on the surfaces of crustacean larvae produce antimicrobial compounds which protect them from

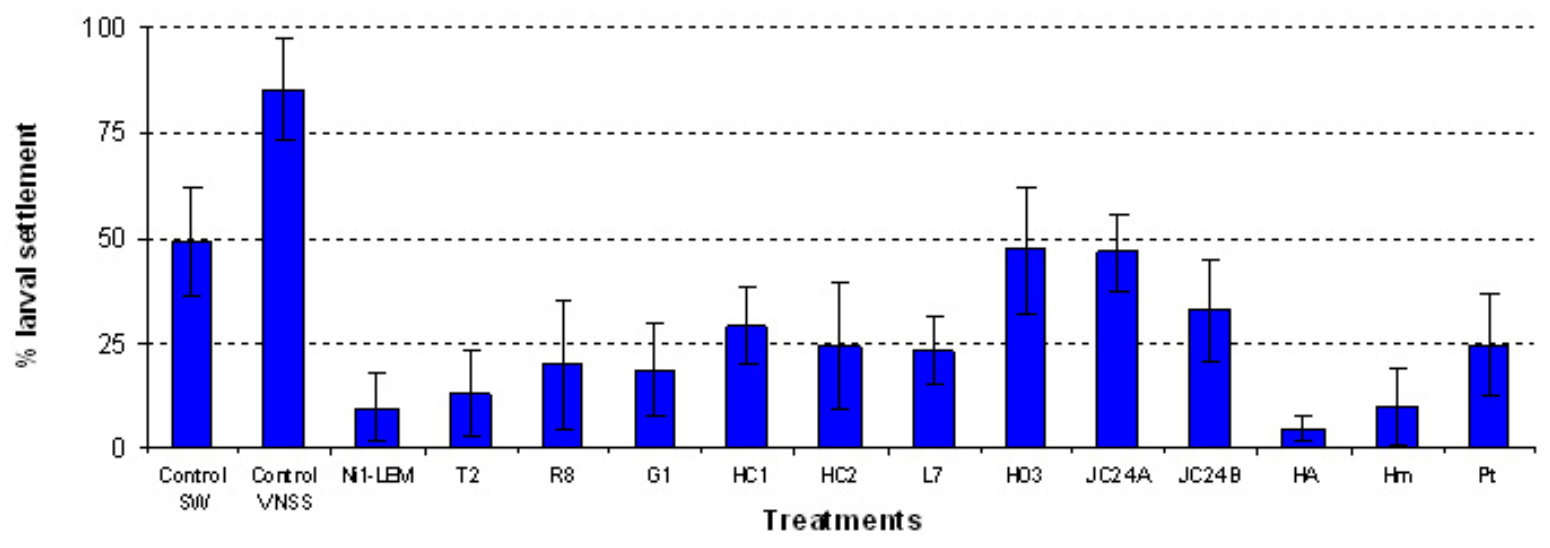

Figure 1. Effect on the settlement of $\boldsymbol{C}$. intestinalis larvae exposed to different bacterial biofilms. Results represent settlement after $48 \mathrm{hrs}$. All results represent means of three replicate trials. Vertical bars $= \pm$ standard errors. 
Table 1. Epibiotic bacterial strains isolated from different substrates.

\begin{tabular}{|c|c|c|}
\hline Organism/Substrate & Code assigned to Bacteria Isolate & $\begin{array}{c}\text { Number } \\
\text { bacterial } \\
\text { strains }\end{array}$ \\
\hline Athyonidium chilensis & $\mathrm{HO} 1, \mathrm{HO} 2, \mathrm{HO} 3, \mathrm{HC} 1, \mathrm{HC} 2, \mathrm{HA}, \mathrm{AA} 1, \mathrm{AA} 3$ & 8 \\
\hline Ciona intestinalis & $\begin{array}{l}\text { T1, T2, T3, T4, T5, T6, T7, T8, T9, T10, JC14, JC19A, CJ19B, CJ24A, } \\
\text { CJ24B, CJ24C }\end{array}$ & 16 \\
\hline Glosophora & G1, G2, G3, G4, G5 & 5 \\
\hline Lithothamnium & L1, L2, L3, L4, L5, L6, L7,L8, L9, L10 & 10 \\
\hline Perumytilus algosus & $\mathrm{CH} 1, \mathrm{CH} 2, \mathrm{CH} 3, \mathrm{CH} 4, \mathrm{CH} 5$ & 5 \\
\hline Rhodymenia & RHO1, RHO2, RHO3, RHO4, RHO5, RHO6, RHO7, R8, Ni1 & 9 \\
\hline Tetrapigus niger & TA1, TA2, TA3, TO1 & 4 \\
\hline Ulva lactuca & U1, U2, U3, U4, U5, U6, U7, U8,U9,U10 & 10 \\
\hline Polypropylene plates & C1, C2,C3, C4, C5, Ni1-LEM & 6 \\
\hline $\begin{array}{l}\text { Total bacterial strains } \\
\text { isolated }\end{array}$ & & 73 \\
\hline
\end{tabular}

fungal infections (Gil-Turnes and Fenical, 1992). Biofilms of the bacteria Pseudoalteromonas tunicata, isolated from the surface of a tunicate, showed antifouling activity against larvae of Balanus amphitrite and $C$. intestinalis (James et al. 1996; Holmström and Kjelleberg, 1999).

Ciona intestinalis (white sea squirt) is an important cosmopolitan fouling organism on both natural and artificial substrates (Connell, 2000; Mazouni et al. 2001). This tunicate produces serious operational difficulties in diverse aquaculture centres, for example in Scotland

(Karayucel, 1997), S. Africa (Hecht and Heasman, 1999), and Chile (Uribe and Etchepare, 2002). In Chile, this problem is particularly costly in the culture of the scallop Argopecten purpuratus, where masses of tunicates weigh down lines and cage culture systems, compete with the scallops for food and oxygen, reduce the transport capacity of small workboats, and require considerable investment in labour and equipment for cleaning culture apparatus (FIP, 1996). Another tunicate, the "red sea squirt" Pyura praeputialis, is an introduced species in Chile which is becoming a dominant component in the rocky intertidal environment near Antofagasta (Castilla et al. 2002) and causes serious problems for scallop culture in this region.

The main objective of the present study was to search for indigenous marine bacteria occurring in biofilms which exerted inhibitory activity on the settlement of larvae of the tunicates common in the fouling of $A$. purpuratus culture systems. A long term goal of this work was to concentrate natural antifouling materials produced by bacteria in a way that they could be employed in fouling prevention without toxic side effects for the organisms in culture. The culture of A. purpuratus has become very important in Chile, making it the world's third largest exporter of scallops. Successful continuation and growth of this enterprise will depend, however, on successful development of measures for the control of its associated marine macrofouling problem.

\section{MATERIALS AND METHODS}

\section{Larval culture}

Ciona intestinalis. Adult $C$. intestinalis were obtained from the El Golfo Culture Center located at San Jorge Bay, Antofagasta, Chile (Lat 23 ${ }^{\circ} 39^{\prime}$ 'S) in spring 2004, and placed in a $500 \mathrm{~L}$ holding aquarium at the nearby Marine Science Faculty, University of Antofagasta. The tank received a constant flow of $10 \mu \mathrm{m}$ filtered seawater at $18^{\circ} \mathrm{C}$ and the ascidians were fed ad libitum with pure cultures of microalgae Chaetoceros calcitrans and Ch. gracilis. Mature individuals of over $60 \mathrm{~mm}$ in length were selected on the basis of the presence of spermatozoa and oocytes in the gonoducts as observed through the (transparent) body wall; these specimens were transferred to $2 \mathrm{~L}$ recipients containing $1 \mu \mathrm{L}$ filtered seawater. Mature oocytes were 


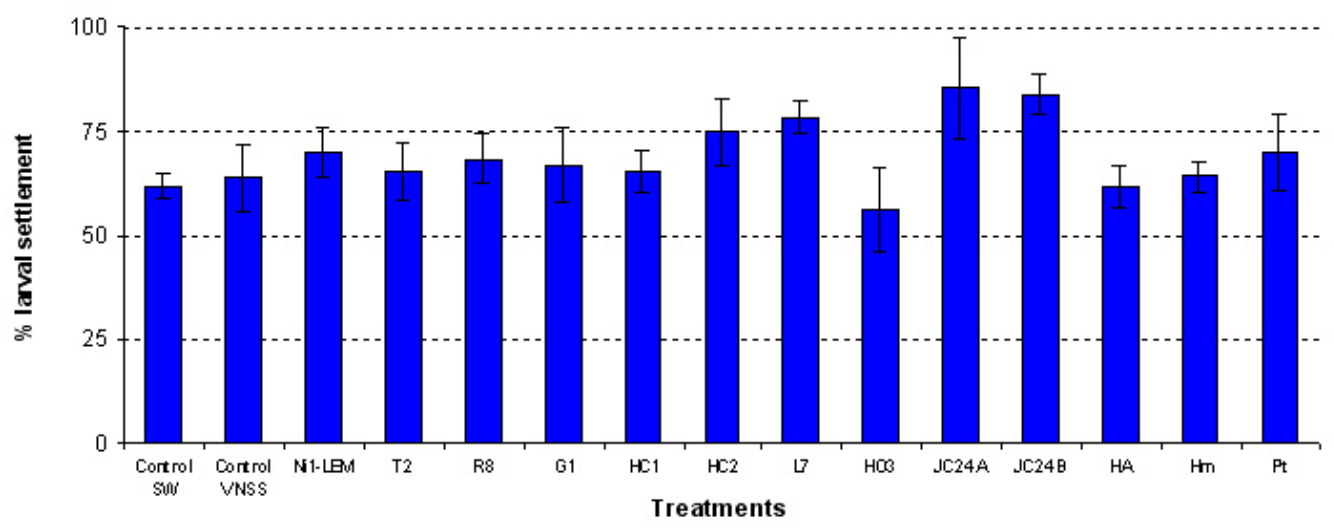

Figure 2. Effect of different chloroform-killed bacterial strains from Figure 1 on settlement of $C$. intestinalis larvae. Results represent settlement after $48 \mathrm{hrs}$. All results represent means of three replicate trials. Vertical bars $= \pm$ standard errors.

collected by dissection of the distal oviduct next to the gonopore; oocytes were aspirated into a micropipette, depositing a total of about 300 oocytes into $15 \mathrm{ml}$ of $0.2 \mu \mathrm{m}$ filtered seawater in a Petri dish. Spermatozoa were collected from the sperm ducts of fresh specimens by the same method. Fertilization of the oocytes was carried out as aseptically as possible in a petri dish, allowing $30 \mathrm{~min}$ for the process. Success of fertilization step was checked using light microscopy at $40 \mathrm{X}$. The zygotes were gently rinsed with three changes of $0.2 \mu \mathrm{m}$ filtered seawater and placed in a beaker with $500 \mathrm{~mL} 0.2 \mu \mathrm{m}$ filtered seawater with aeration, and maintained at $18^{\circ} \mathrm{C}$ until the larval stage was reached.

Pyura praeputialis. Adult specimens were collected at low tide from the rocky intertidal zone near Antofagasta (Lat $23^{\circ} 39^{\prime} \mathrm{S}$ ) in spring 2004, and were returned to the laboratory and handled similarly to $C$. intestinalis (above). Artificial fertilization was carried out using the techniques previously described by Clarke et al. (1999).

\section{Bacterial isolations}

Natural and artificial substrates sampled for naturally occurring film-forming bacteria are listed in Table 1. These were rinsed copiously with sterile seawater to remove debris and weakly adhered microorganisms (Jiang et al. 1999). Samples of strongly adherent epibiotic bacteria were obtained using a bacteriological loop. Samples were spread on TCBS Agar (Oxoid Ltd.) and Zobell 2216 Marine Agar (Difco, Detroit, Michigan, USA). The TCBS agar plates were incubated at $20^{\circ} \mathrm{C}$ for $48 \mathrm{hrs}$, and marine agar plates at the same temperature for one week. Once the colonies had developed, isolates were obtained by using a sterile loop and by spreading on TSA agar supplemented with $2 \% \mathrm{NaCl}$ (TSA2) (Oxoid Ltd.). Various criteria were used in the selection of a broad variety colonies, including pigmentation, consistency, swarming behaviour, and others, which aided in recognizing them on the TSA agar (Table 1). Two bacterial strains previously known to inhibit invertebrate larval settlement were included in the study as positive controls, including Pseudoalteromonas tunicata (Pt) provided by Dr. S. Kjelleberg and Halomonas marina (Hm) (Dobson and Franzmann, 1996) was obtained from the American Type Culture Collection (Manassas, Virginia, USA).

A preliminary characterization of the bacterial strains had inhibitory effects on the settlements of $C$. intestinalis larvae (Gram reaction and motility) was made using light microscopy. The biochemical tests catalase and $\mathrm{O} / \mathrm{F}$ reaction with glucose (Gerhardt et al. 1994) were also carried out.

\section{Preparation of bacterial films and their effects on C . intestinalis larval settlement}

Biofilms were prepared from the 73 bacterial strains isolated, as well as from the two control species, using the methodology given by Maki et al. (2000). Overnight bacterial cultures grown in the medium VNSS, (Holmström et al. 1998) were centrifuged at $5520 \mathrm{x}$ g for $15 \mathrm{~min}$. The pellet was washed and resuspended in artificial seawater (ASW, "Sea Salt", Sigma Co.), and re-centrifuged. The pellet was then resuspended in $1 / 10 \mathrm{VNSS} / \mathrm{ASW}$. The bacterial count in this suspension was determined using DAPI (4',6'-diamidino-2-phenyllindole) solution (ca. $1 \mu \mathrm{g}$ $\mathrm{mL}^{-1}$ ), followed by observation with a fluorescence microscope (Olympus BH-2) within 30 min (Kogure et al. 1998). Three $\mathrm{mL}$ of each bacterial suspension, at a concentration of $10^{8}$ cells $\mathrm{mL}^{-1}$, were deposited into $30 \mathrm{~mm}$. diameter polystyrene dishes, which were then incubated at $20^{\circ} \mathrm{C}$ for $48 \mathrm{hrs}$. The culture medium was then decanted and the plates were rinsed 3 times with ASW to eliminate cells which were not adhered to the substrate. Controls were prepared by the above steps, but omitting bacteria from the system. An additional set of trials included preparation of a parallel set of bacterial films which were then killed by a 30 min exposure to chloroform fumes. 
Table 2. Comparison of results from the present study with similar studies on other invertebrates and one algal species.

\begin{tabular}{|l|c|c|c|c|}
\hline \multicolumn{1}{|c|}{ Test species } & $\begin{array}{c}\text { \# bacterial } \\
\text { strains isolated }\end{array}$ & \% positive & effect tested & reference \\
\hline C. intestinalis & 73 & 20 & settlement & present study \\
\hline P. praeputialis & 73 & 20 & settlement & present study \\
\hline C. intestinalis & 40 & 12.5 & settlement & Holmstrom et al. 1992 \\
\hline B. amphitrite & 40 & 12.5 & settlement & Holmstrom et al. 1992 \\
\hline B. amphitrite & 16 & 64 & settlement & Mary et al. 1993 \\
\hline Hydroides elegans & 11 & 18 & settlement & Dobretsov and Quian, 2004 \\
\hline Ulva (spores) & 56 & 23 & spore germination & Egan et al. 2001 \\
\hline
\end{tabular}

Larvae settlement assays of $C$. intestinalis were done by introducing 15 larvae in a total of $3 \mathrm{ml}$ seawater into all dishes containing living and killed bacterial biofilms, plus controls without bacterial films. The systems were incubated at $18^{\circ} \mathrm{C}$ for $48 \mathrm{hrs}$, and then observed using an inverted microscope to determine the numbers of settled and non-settled tunicate larvae. The percentage settlement as then calculated for all systems. Three replicate trials were made in all the experiments.

\section{Preparation of bacterial extracellular products (EP)}

Extracellular fractions were prepared from bacterial strains Nil-LEM and HA, and the positive controls Pt and Hm, all of which had been cultured to the stationary phase in Marine Minimal Medium (MMM) (Maki et al. 2000) with constant stirring at room temperature $\left(18^{\circ} \mathrm{C}\right)$. The cultures were centrifuged at $18600 \mathrm{x} \mathrm{g}$ for $15 \mathrm{~min}$ at $4^{\circ} \mathrm{C}$, and the supernatant was filtered twice to $0.2 \mu \mathrm{m}$ and stored at $70^{\circ} \mathrm{C}$.

\section{Inert matrix preparation for larvae settlement assays of $\boldsymbol{C}$. intestinalis and $\boldsymbol{P}$. praeputialis}

The inert polymer Phytage ${ }^{\mathrm{TM}}$ (Sigma Chemical Company), was prepared by diluting $0.326 \mathrm{~g}$ of the product in $20 \mathrm{~mL}$ of distilled water with stirring, and then heated for $60 \mathrm{sec}$ in a microwave oven, to reach $80^{\circ} \mathrm{C}$. At the same time, the extracellular products from the four bacterial strains obtained above were brought to $45-50^{\circ} \mathrm{C}$, and incorporated into the Phytagel. Testing as carried out using two different final dilutions (1:2 and 1:10) of the EP in the Phytagel. Controls were prepared with Phytagel only, Phytagel with sterile seawater, and Phytagel with MMM. TwentymL of the molten Phytagel were deposited in $30 \mathrm{~mm}$ polystyrene petri dishes and allowed to solidify at room temperature. Each experimental and control plates received three $\mathrm{ml}$ aliquots of seawater containing $15 C$. intestinalis larvae; and a parallel test was run using the same numbers of $P$. praeputialis larvae. Settlement of the larvae in each plate was determined after $48 \mathrm{hrs}$ by direct observation in an inverted microscope.

\section{EP heat treatment}

In order to determine the effects of heat treatment on the bacterial $\mathrm{EP}$, the extracts were treated at $80^{\circ} \mathrm{C}$ in an incubator bath for $30 \mathrm{~min}$, and allowed to cool to room temperature, filtered to $0.2 \mu \mathrm{m}$. The normal and heat treated EP were tested in parallel on their capacity to inhibit settlement of $C$. intestinalis and $P$. praeputialis larvae.

\section{EP fractionation}

The approximate molecular size bacterial antifouling compounds was determined using dialysis by fractionation from bacterial strains Nil-LEM and HA by dialysis against sterile distilled water for $12 \mathrm{hrs}$ at $4^{\circ} \mathrm{C}$ with benzoilated membranes (Sigma Co.) with a cut-off of 3,500 and 10,000 Da. The dialysates were filtered to $0.2 \mu \mathrm{m}$. and used in larval settlement tests. Controls included seawater and MMM.

\section{Enzymatic treatment of the EP}

An assay was carried out to determine if the EP factors inhibitory to tunicate settlement were proteic or peptidic in nature. For this the EP were separately treated at a final concentration of $200 \mu \mathrm{gmL}^{-1}$ pronase $\mathrm{E}$ and carboxypeptidase $\mathrm{G}$. The pronase $\mathrm{E}$ mixture was incubated at $37^{\circ} \mathrm{C}$ for two $\mathrm{h}$ and the carboxypeptidase $\mathrm{G}$ at $30^{\circ} \mathrm{C}$ for 3 hrs, both at $\mathrm{pH}$ 7.1. The treated $\mathrm{PE}$ were then heated to $80^{\circ} \mathrm{C}$ for $20 \mathrm{~min}$ to inactivate all proteic and enzymatic activity. Controls for both treatments included seawater and MMM substituted for EP. 


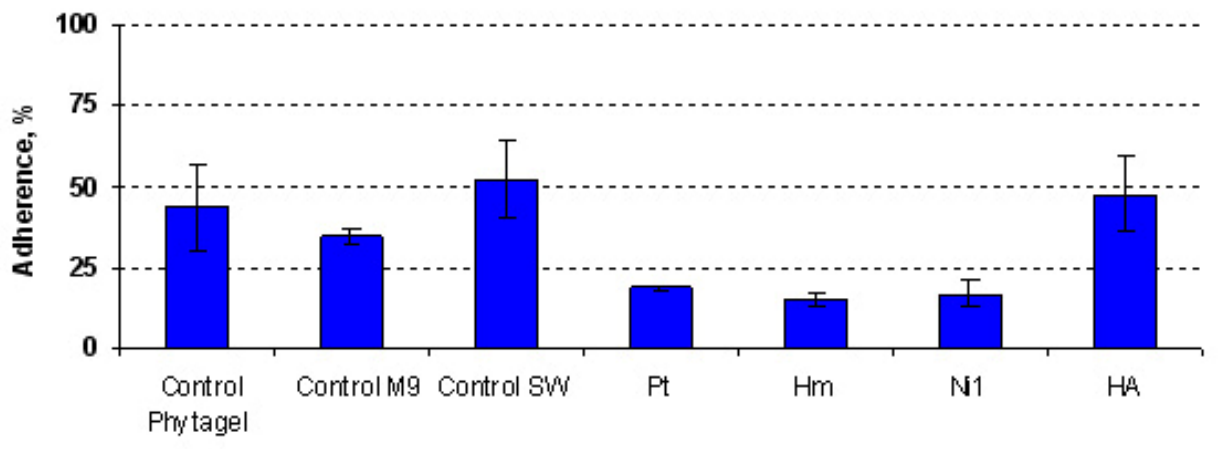

Treatments

Figure 3. The effect of bacterial extracellular products (EP) incorporated into Phytagel ${ }^{\mathrm{TM}}$ on the settlement of $C$. intestinalis larvae after $48 \mathrm{hrs}$ incubation. Results represent the means of three replicate assays. Vertical bars $= \pm$ standard errors.

\section{Separation of EP fractions using high pressure liquid chromatrography (HPLC)}

The supernatants from pre-stationary phase cultures of the bacterial strain Ni1-LEM were concentrated by vacuum evaporation at $70^{\circ} \mathrm{C}$ (Rotavap Büchi) for 4 hrs. One-mL samples were then separated by HPLC on a $\mathrm{C}_{18}$ column with in a gradient of acetonitrile:water with $0.1 \%$ trifluoroacetic acid. Fractions were collected at 4, 5, 6, 7, 8, 9, 13, 17 and $18 \mathrm{~min}$ intervals. One-mL fractions were collected and concentrated by vacuum centrifugation in a speedvac (Centrivap console, Labconco), at $60^{\circ} \mathrm{C}$ and were used in bioassays for antifouling activity using five larvae/ml of $C$. intestinalis and $P$. praeputialis. This assay was carried out in multi-well polystryrene plates, with 30 $\mathrm{mm}$ diameter wells, containing $3 \mathrm{~mL}$ seawater with 15 larvae per well. Controls were run, as previously, with seawater and MMM substituted for EP. The numbers of larvae settled were determined by observation with an inverted microscope after $48 \mathrm{hrs}$ incubation as in other trials (above).

\section{Statistical analyses}

One-way analyses of variance (ANOVA, $\alpha=0.05$ ) were used to evaluate the effects of both living and non-living biofilms, as well as the effects of the bacterial extracellular components, on the inhibition of $C$. intestinalis and $P$. praeputialis larvae settlement. The determination of the factors which were responsible for significant differences was carried out using a multiple comparison, test (TukeyHSD).

\section{RESULTS}

\section{Effect of the bacterial biofilm on C. intestinalis}

A total of 73 film-forming bacterial strains were isolated (Table 1). The assays with living bacterial films showed that $20 \%$ of the strains had inhibitory effects on the settlement of $C$. intestinalis larvae; strong inhibition was indicated when $50 \%$ or more of the larvae present failed to settle in the plates. These bacterial strains isolated were gram-negative, fermentative, positive for motility and catalase.

Figure 1 shows the bacterial strains having the highest antifouling effects, as well as the positive (Hm, Pt) and negative controls. Significant differences were observed in averages of non-settled larvae between treatments and negative controls (ANOVA, $\mathrm{p}<0.05$ ).

The inhibitory ability of the biofilms was lost when they were tested in the non-living condition, as shown by Figure 2. No significant differences were found in the percentages of non-adhered larvae between (non-living) biofilmed surfaces and controls (ANOVA, $\mathrm{p}<0.05$ ).

\section{Effect of immobilized PE on larvae of $C$. intestinalis}

The extracellular products incorporated into the Phytagel which had inhibitory effect was strain Ni1-LEM (16.8\%). Significant differences (ANOVA, $p<0.05$ ) occurred between the results obtained with strains $\mathrm{Pt}, \mathrm{Hm}$ (positive controls) and Ni1-LEM, and the negative controls (Figure $3)$.

\section{Effect of bacterial EP on $C$. intestinalis and $P$. praeputialis larvae}

The EP from bacterial strains Pt, Hm and Ni1-LEM did not lose their ability to inhibit settlement of larval $C$. intestinalis and $P$. praeputialis after dilution and/or denaturation (Figure 4 and Figure 5). Here, significant differences were detected between the treatments and the negative controls (ANOVA, $\mathrm{p}<0.05$ ). The bacterial strains $\mathrm{Pt}, \mathrm{Hm}$, and Ni1-LEM lost their antifoulimg activity against C. intestinalis after exposure to protease, although peptidase had no effect. A contrasting result was obtained with strain HA (Figure 4) which lost its antifouling activity after exposure to peptidase, but not with protease. This 


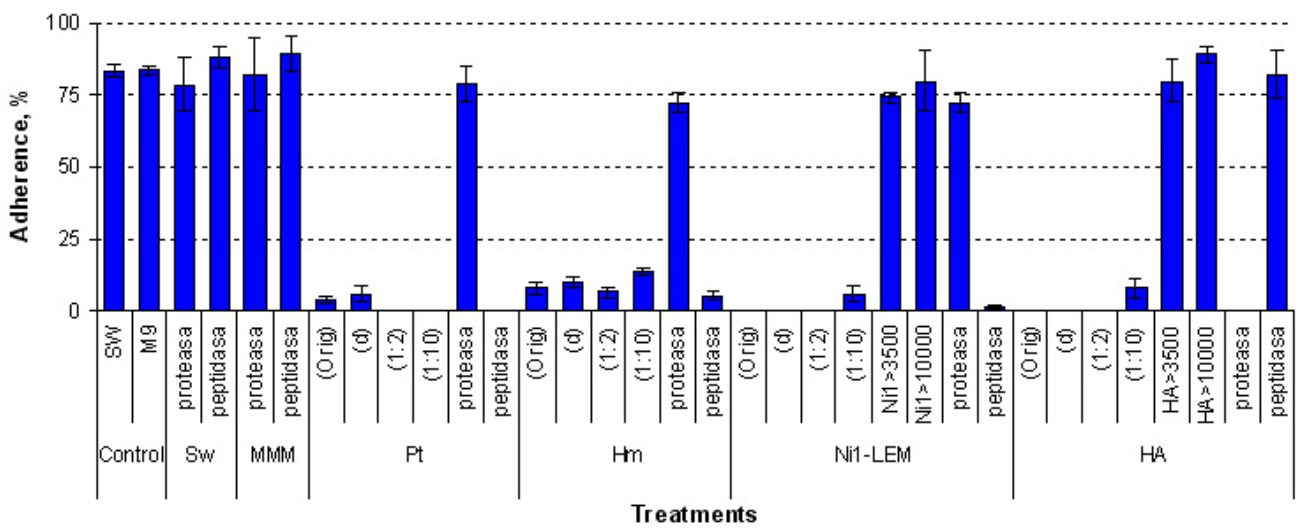

Figure 4. Effects of bacterial extracellular products (EP) on settlement of $\boldsymbol{C}$. intestinalis larvae after a $48 \mathrm{hrs}$ incubation. $($ Orig) $=$ untreated EP; (d) = heat denatured EP; $(1: 2)$ and (1:10) = EP dilutions; Ni1 > 3,500 and Ni1 > 10,000 = dialyzed fractions of EP; protease and peptidase $=\mathrm{EP}$ enzymatic treatments. All values are the results of three replicate trials. Controls: $\mathrm{SW}=\mathrm{seawater} ; \mathrm{MMM}=$ marine minimal medium; $\mathrm{Pt}$ and $\mathrm{Hm}=$ positive control bacterial strains. Vertical bars $= \pm$ standard errors.

could be indicate that EP of the strain HA are peptide origin.

Figure 5 shows that the EP of strains Pt, Hm, Nil-LEM and HA lost their inhibitory effect against $P$. praeputialis, after treatment with proteolytic enzymes. Dialysis of the PE showed that substances inhibitory to the settlement of $C$. intestinalis and $P$. praeputialis larvae produced by strains Ni1-LEM and HA had molecular weights of less than 3,500 Da.

\section{Effect of EP HPLC fractions on settlement of $C$. intestinalis and $P$. praeputialis larvae}

Figure 6a shows the results with the EP fractions obtained by separation with an HPLC column on larvae settlement of the two ascidian species used in this study. Only the fourand five-minute column eluates of the PE from bacterial strain Nil-LEM inhibited larval settlement of the two ascidian species (Figure 6a). The remaining fractions produced no significant differences from the controls (ANOVA, $\mathrm{p}<0.05$ ).

\section{DISCUSSION}

The present results are in general agreement with results obtained by other authors working with various species as listed in Table 2.

The results of these studies and those of the present study showed that bacteria present in biofilms may have an important role in the development of trophic successions in benthic micro systems based on inhibitory ability of microfouling components of the intertidal zone. The presence of the inhibitory bacteria can influence the normal development and survival of some invertebrates and algae (Egan et al. 2001). The inhibitory ability of these biofilms is lost after killing with chloroform (Figure 2), suggesting

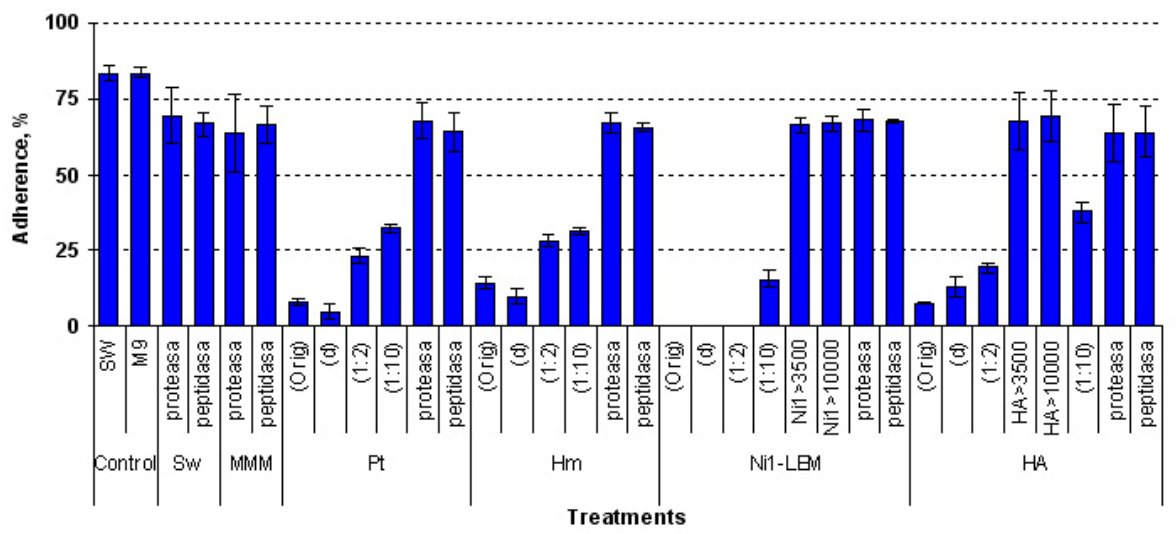

Figure 5. Effects of bacterial extracellular products (EP) on settlement of $\boldsymbol{P}$. praeputialis larvae after a $\mathbf{4 8}$ hrs incubation. (Orig) $=$ untreated EP; $(\mathrm{d})=$ heat denatured EP; $(1: 2)$ and (1:10) = EP dilutions; Ni1 > 3,500 and Ni1 > 10,000 = dialyzed fractions of EP; protease and peptidase $=$ EP enzymatic treatments. All values are the results of three replicate trials. Controls: $\mathrm{SW}=\mathrm{seawater} ; \mathrm{MMM}=$ marine minimal medium; $\mathrm{Pt}$ and $\mathrm{Hm}=$ positive control bacterial strains. Vertical bars $= \pm$ standard errors. 
that the production of inhibitory substances is an activity inherent to the metabolism of living cells. In preliminary test chloroform fumes, no affects the activity inhibitory (data unpublished).

Incorporation of bacterial inhibitory substances in a gel matrix is a model system representing a method for applying antifouling substances onto surfaces in need of antifouling protection in the sea. The antifouling compounds can be incorporated into the matrix at concentrations higher than those in the natural environment without altering the physical characteristics of the settlement surface (Henrikson and Pawlik, 1995). This technique is valuable for assaying the antifouling effects of secondary metabolites produced by marine organisms (Henrikson and Pawlik, 1998). Phytagel ${ }^{\mathrm{TM}}$ was chosen for the present study due to its stability when compared with other potentially useful polymers. Henrikson and Pawlik (1995) have reviewed these properties related to their in situ studies with extracts from marine invertebrates. As noted above, the inhibitory ability of bacterial extracellular products was not inhibited by their inclusion in Phytagel, with one bacterial strain (HA) as an exception (Figure 3). The observed increases of effectiveness of the bacterial extracellular products with higher concentration (Figure 4 and Figure 5) were similar to the results of Thiyagarajan et al. (1999), where low concentrations of extracts did not affect settlement of B. meticulatus, but high concentrations did.

Our results suggest that the bacterial inhibitory substances are thermostable, proteic or peptidic substance of less than $3500 \mathrm{Da}$ in MW (strain Ni1-LEM); this agrees with Holmström and Kjelleberg (1999) and Egan et al. (2001) that low molecular weight peptides or proteins inhibited the settlement of bacteria, fungi, microalgae, algal spores, and invertebrates. In contrast, Dobretsov and Qian (2004) found that inhibitory substances isolated from bacteria from the soft coral Dendronephthya $s p$ had a molecular weight of greater than $100 \mathrm{KDa}$.

The results obtained from the HPLC analyses suggested that the protein or peptide present in the active fraction had polar characteristics (in preliminary experiments it was test, data no show) (Figure 6), similarly to that reported by Egan et al. (2001), polar proteins and low molecular weight, which inhibited the germination of Ulva lactuca spores. Previously, Kawamata et al. (1994) reported that substances

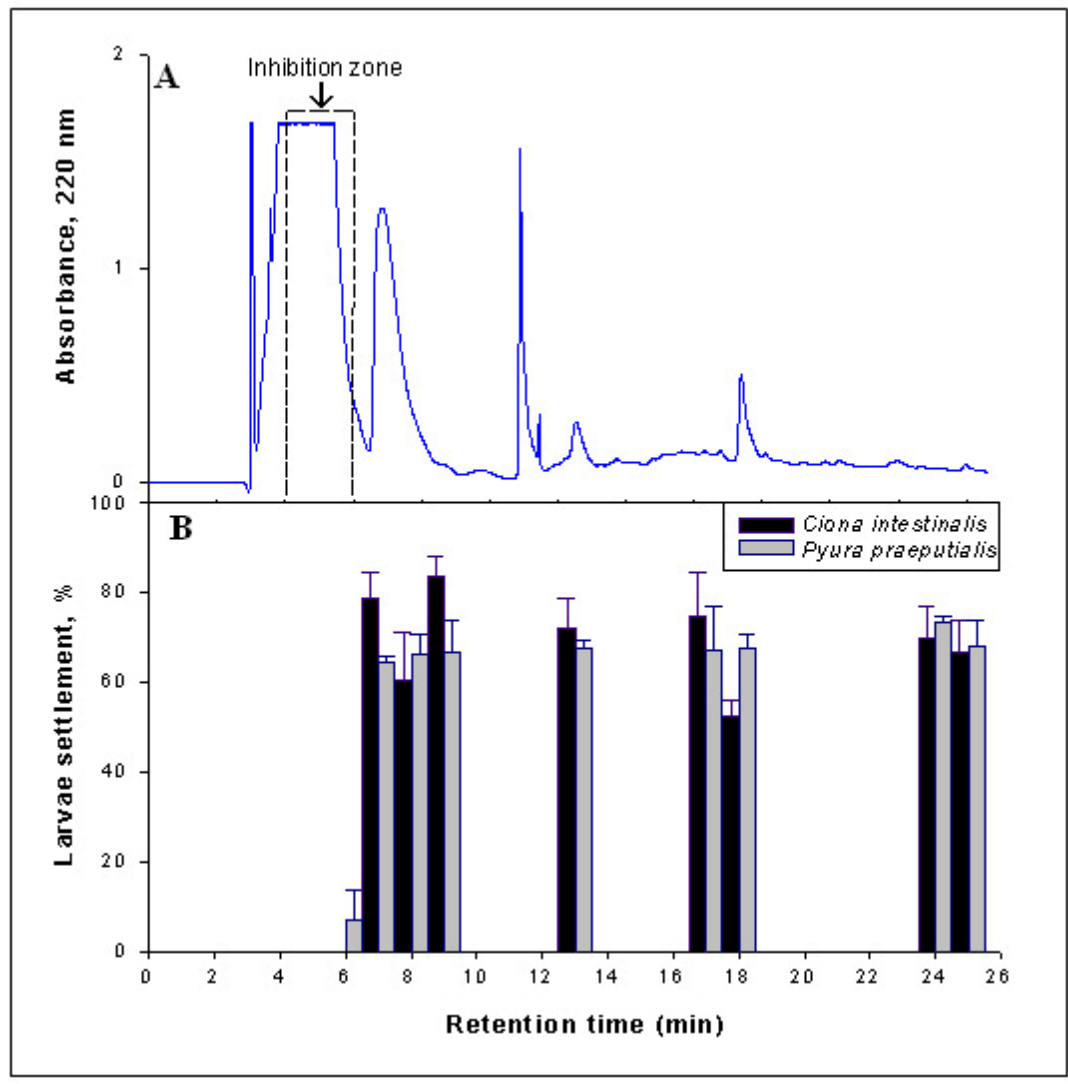

Figure 6. Larval settlement results obtained with strain Ni1-LEM EP fractions separated by HPLC. (a) The chromatograph shows absorbance of the EP at $220 \mathrm{~nm}$ over time ( $\mathrm{min})$. The broken line represents fractions showing antisettlement activity.

(b) Effects of HPLC-separated PE fractions from bacterial strain Ni1-LEM on larvae settlement of $C$. intestinalis and $P$. praeputialis after a $\mathbf{4 8} \mathbf{~ h r s}$ incubation. All results are means of three replicate trials. Vertical bars $= \pm$ standard errors. 
from the soft coral Dendronephthya $s p$ which inhibited the settlement of Balanus amphitrite larvae were water soluble and of low molecular weight. Although, we can not dismissed the presence of other compounds of other chemical nature present in the bacterial supernatants.

Indirect evidence, as well as newly emerging experimental evidence, suggests that many marine species have variable abilities for protecting themselves from overgrowth by natural competitors and neighbours within their communities. Protective substances may be produced directly by the organisms, or may be products from microbial symbionts or incidental microbial film-formers in the habitat. In any case, extracellular metabolites with antifouling activity are metabolic products representing an energy cost to the producers, which may be why in the few reports we have seen (Table 2) bacterial antifouling activity has been relatively low (only $20 \%$ of the strains were active in the present study). It is of pressing interest to find unique substances of bacterial or other origin which would be useful for incorporation into antifouling coatings of practical use. As is well known for existing chemical antifouling coatings such as those containing copper or TBT, they are designed to release considerable quantities of highly toxic substances to be effective over time. It is therefore essential to find naturally repellent products with a broad spectrum activity and capable of being made available in commercial quantities.

The present study is part of the beginning of an effort to find natural products which in the future will fulfil emerging needs for antifouling products which repel classically damaging invertebrates, while at the same time allowing the growth of desirable species in aquaculture.

\section{ACKNOWLEDGMENTS}

The authors thank Drs. Suelen Egan and Staffan Kjelleberg of the Center for Marine Biofouling and Bioinvasion, U. of New South Wales, Australia, for providing the strain of $P$. tunicata. We also thank Prof. Marcela Clarke for assistance in obtaining and handling larvae of $C$. intestinalis and $P$. praeputialis.

\section{REFERENCES}

ARMSTRONG, Evelyn; BOYD, Kenneth G.; PISACANE, Tony; PEPPIAT, C.J. and BURGESS, J. Grant. Marine microbial natural products in antifouling coatings. Biofouling, 2000, vol. 16, no. 2-4, p. 215-224.

BURGESS, J. Grant; BOYD, Kenneth G.; ARMSTRONG, Evelyn; JIANG, Zhong; YAN, Liming; BERGGREN, Matz; MAY, Ulrika; PISACANE, Tony; GRANMO, Ake and ADAMS, David R. The development of a marine natural product-based antifouling paint. Biofouling, 2003, vol. 19, no. 1, p. 197-205.

BOYD, K.G.; MEARNS-SPRAGG, A.; BRINDLEY, G.; HATZIDIMITROU, K.; RENNIE， R.; BREGU, M.;
HUBBLE, M.O. and BURGESS, J.G. Antifouling potential of epiphytic marine bacteria from the surfaces of algae. In: LE GAL, Y. and MULLER-FEUGA, Arnaud eds. Marine Microorganisms for Industry, Microorganismes marins pour l'industrie. Editions IFREMER, Plouzané, France, 1998, p. 128-136.

BOYD, Kenneth G.; ADAMS, David R. and BURGESS, J. Grant. Antibacterial and repellent activity of marine bacteria associated with algal surfaces. Biofouling, 1999, vol. 14, no. 3, p. 227-236.

BOYD, Kenneth G.; MEARNS-SPRAGG, A. and BURGESS, J. Grant. Screening of marine bacteria for the production of microbial repellents using a spectrophotometric chemotaxis assay. Marine Biotechnology, July 1999, vol. 1, no. 4, p. 359-363.

CASTILLA, J.C.; COLLINS, A.C.; MEYER, C.P.; GUIÑEZ, R. and LINDBERG, D.R. and LINDBERG, D. Recent introduction of the dominant tunicate, Pyura praeputialis (Urochordata, Pyuridae) to Antofagasta, Chile. Molecular Ecology, August 2002, vol. 11, no. 8, p. 15791584.

CLARE, A.S. Marine natural product antifoulants: status and potential. Biofouling, 1996, vol. 9, no. 3, p. 211-229.

CLARKE, M.; ORTIZ, V. and CASTILLA, J.C. Does early development of the Chilean tunicate Pyura praeputialis (Heller, 1878) explain the restricted distribution of this species? Bulletin of Marine Science, 1999, vol. 65, p. 745754.

CONNELL, Sean D. Floating pontoons create novel habitats for subtidal epibiota. Journal of Experimental Marine Biology and Ecology, May 2000, vol. 247, no. 2, p. 183-194.

DOBRETSOV, Sergey V. and QIAN, Pei-Yuan. Effect of bacteria associated with the green alga Ulva reticulata on marine micro-and macrofouling. Biofouling, 2002, vol. 18, no. 3, p. 217-228.

DOBRETSOV, Sergev V. and QIAN, Pei-Yuan. The role of epibiotic bacteria from the surface of the soft coral Dendronephtya $\mathrm{sp}$. in the inhibition of larval settlement. Journal of Experimental Marine Biology and Ecology, February 2004, vol. 299, no. 1, p. 35-50.

DOBSON, S.J. and FRANZMANN, P.D. Unification of the genera Deleya (Baumann et al. 1983), Halomonas (Vreeland et al. 1980), and Halovibrio (Fendrich, 1988) and the species Paracoccus halodenitrificans (Robinson and Gibbson, 1952) into a single genus; Halomonas, and placement of the genus Zymobacter in the family Halomonadaceae. International Journal of Systematic Bacteriology, April 1996, vol. 46, no. 2, p. 550-558. 
EGAN, Suhelen; JAMES, Sally; HOLMSTRÖM, Carola and KJELLEBERG, Staffan. Inhibition of algal spore germination by the marine bacterium Pseudoalteromonas tunicata. FEMS Microbiology Ecology, March 2001, vol. 35 , no. 1 , p. 67-73.

FIP (Fisheries Research Fund). Technical Report FIPIT/96-55. Investigación de variables que influyen en el desarrollo del piure blanco en cultivos de ostión. Universidad Católica del Norte, Coquimbo. Chile, 1996, p. 110.

FISHER, W.S.; OLIVER, L.M.; WALKER, W.W.; MANNING, C.S. and LYTLE, T.F. Decreased resistance of eastern oysters (Crassostrea virginica) to a protozoan pathogen (Perkinsus marinus) after sublethal exposure to tributyltin oxide. Marine Environmental Research, March 1999, vol. 47, no. 2, p. 185-201.

GERHARDT, P.; MURRAY, R.G.E.; WOOD, W.A. and KRIEG, N.R. Methods for General and Molecular Bacteriology. American Society for Microbiology, Washington, 1994, 791 p. ISBN 1-55-581048-9.

GIL-TURNES, M.S. and FENICAL, W. Embryos of Homarus americanus are protected by epibiotic bacteria. The Biological Bulletin, February 1992, vol. 182, no. 1, p. 105-108.

GRINWIS, G.C.M.; BOONSTRA, A.; VAN DEN BRANDHOF, E.J.; DORMANS, J.A.M.A.; ENGELSMA, M.; KUIPER, R.V.; VAN LOVEREN, H.; WESTER, P.W.; VAAL, M.A.; VETHAAK, A.D. and VOS, J.G. Short-term toxicity of bis (tris-n-butylin) oxide in flounder (Platichthys flesus): Pathology and immune function. Aquatic Toxicology, May 1998, vol. 42, no. 1, p. 15-36.

HARDER, Tilmann; LAU, Stanley C.K.; DOBRETSOV, Sergey; FANG, Tsz K. and QIAN, Pei-Yuan. A distinctive epibiotic bacterial community on the soft coral Dendronephthya sp. and antibacterial activity of coral tissue extracts suggest a chemical mechanism against bacterial epibiosis. FEMS Microbiology Ecology, April 2003, vol. 43, no. 3, p. 337-347.

HECHT, Thomas and HEASMAN, Keavin. The culture of Mytilus galloprovincialis in South Africa and the carrying capacity of mussel farming lfz Saldanha Bay. World Aquaculture Society, 1999, vol. 30, no. 4, p. 50-55.

HENRIKSON, Alicia A. and PAWLIK, Joseph R. A new antifouling assay method: results from field experiments using extracts of four marine organisms. Journal of Experimental Marine Biology and Ecology, December 1995, vol. 194, no. 2, p. 157-165.

HENRIKSON, Alicia A. and PAWLIK, Joseph R. Seasonal variation in biofouling of gels containing extracts of marine organisms. Biofouling, 1998, vol. 12, no. 1-3, p. 245-255.
HENTSCHEL, Ute; SCHMID, Michael; WAGNER, Michael; FIESELER, Lars; GERNERT, Christine and HACKER, Jörg. Isolation and phylogenetic analysis of bacteria with antimicrobial activities from Mediterranean sponges Aplysina aerophoba and Aplysina cavernicola. FEMS Microbiology Ecology, May 2001, vol. 35, no. 3, p. 305-312.

HOLMSTRÖM, Carola; RITTSCHOF, Dan and KJELLEBERG, Staffan. Inhibition of settlement by Larvae of Balanus amphitrite and Ciona intestinalis by a surfacecolonizing marine bacterium. Applied and Environmental Microbiology, July 1992, vol. 58, no. 7, p. 2111-2115.

HOLMSTRÖM, Carola; JAMES, S.; NEILA, B.; WHITE, D. and KJELLEBERG, Staffan. Pseudoalteromonas tunicata sp. nov., a bacterium that produces antifouling agents. International Journal of Systematic Bacteriology, October 1998, vol. 48, no. 4, p. 1205-1212.

HOLMSTRÖM, Carola and KJELLEBERG, Staffan. Marine Pseudoalteromonas species are associated with higher organisms and produce biologically active extracellular agents. FEMS Microbiology Ecology, December 1999, vol. 30, no. 4, p. 285-293.

JAMES, Sally G.; HOLMSTRÖM, Carola and KJELLEBERG, Staffan. Purification and characterization of a novel antibacterial protein from marine bacterium D2. Applied and Environmental Microbiology, August 1996, vol. 62 , no. 8 , p. $2783-2788$.

JIANG, Zhi-Dong; JENSEN, Paul R. and FENICAL, William. Lobophorins A and B, new antiinflammatory macrolides produced by a tropical marine bacterium. Bioorganic and Medicinal Chemistry Letters, July 1999, vol. 9 , no. 14 , p. 2003-2006.

KARAYUCEL, S. Mussel culture in Scotland. World Aquaculture Society, 1997, vol. 28, p. 4-10.

KAWAMATA, M.; KON-YA, K. and MIKI, W. Trigonelline, an antifouling substance isolated from an octocoral Dendronephthya sp. Fisheries Science, 1994, vol. 60 , p. $485-486$.

KOGURE, Kazuhiro; IKEMOTO, Eiko and MORISAKI, Hisao. Attachment of Vibrio alginolyticus to glass surfaces is dependent on swimming speed. The Journal of Bacteriology, February 1998, vol. 180, no. 4, p. 932-937.

MAKI, J.S.; DING, L.; STOKES, J.; KAVOURAS, J.H. and RITTSCHOF, D. Substratum/Bacterial interaction and larval attachment: Films and exopolysaccharides of Halomonas marina (ATCC 25374) and their effect on barnacle cyprid larvae, Balanus amphitrite Darwin. Biofouling, 2000, vol. 16, no. 2-4, p. 159-170.

MARY, Avelin; MARY, Vitalina; RITTSCHOF, D. and NAGABHUSHANAM, R. Bacterial-barnacle interaction: 
Potential of using juncellins and antibiotics to alter structure of bacterial communities. Journal of Chemical Ecology, October 1993, vol. 19, no. 10, p. 2155-2167.

MAZOUNI, N.; GAERTNER, J.-C. and DESLOU-PAOLI, J.-M. Composition of biofouling communities on suspended oyster cultures: an in situ study of their interactions with the water column. Marine Ecology Progress Series, April 2001, vol. 214, p. 93-102.

PEPPIATT, C.J.; ARMSTRONG, E.; PISACANE, T. and BURGUESS, J.G. Antibacterial activity of resin based coatings containing marine microbial extracts. Biofouling, 2000 , vol. 16 , no. $2-4$, p. 225-234.

THIYAGARAJAN, V.; $\quad$ MURTHY, $\quad$ S.P.; NANCHARAIAH, Y.V.; VENUGOPALAN, V.P.; NAIR, K.V.K. and SUBRAMONIAM, T. Influence of biofilms on the larval settlement of Balanus reticulstus Utinomi (Cirripedia: Crustacea). Biofilm, 1999, vol. 4, paper (BF99001). Available from Internet: http://www.bioline.org.br/abstract?id=bf99001\&lang=en.

URIBE, E. and ETCHEPARE, I. Effects of biofouling by Ciona intestinalis on suspended culture of Argopecten purpuratus in Bahía Inglesa, Chile. Bulletin of the Aquaculture Association of Canada, 2002, vol. 102, p. 9395. 